\title{
Malay Maritime World in Southeast Asia
}

\author{
Bondan Kanumoyoso \\ Department of History, Faculty of Humanities, \\ Universitas Indonesia
}

\begin{abstract}
The development of maritime activities in Southeast Asia in the Received:

"Age of Commerce" was strongly support by the Malay people. 28 Juni 2018 although Westerners have begun to dominate maritime activities in the region since the 17th century, but in the same period Malays and their trading networks continue to perform their irreplaceable function of connecting the various maritime communities that scattered throughout Southeast Asia. The extent of the Malay trade network was one of the factors that shape the maritime character of Southeast Asia. However, Malay trading activities was not only encouraged economic development in this region, but also form an identity that can be called as Malay maritime world of Southeast

Revised:

1 July 2018

Accepted:

2 July 2018

Corresponding author:

bondan_kanumoyoso@yahoo.com Asia. This article examines the maritime characteristic of Malay world and how global trade actually strengthens the role of Malay in trade and other maritime activities.
\end{abstract}

Keywords: Malay; Maritime World; Southeast Asia; Trade Network; Global Trade.

\section{Introduction}

The number of Malay people is not the majority among other ethnicities in Southeast Asia. Different with most ethnicities in the region that have a single place of origin, until now the place of origin of Malay people is still being debated among scholars. The Malay world as it is understood today spread over peninsular Malaysia, the east coast of Sumatra, the west and southwest coast of Borneo, and the Riau Archipelago. Except in Indonesia and Malaysia, nowadays Malay people in Southeast Asia are also can be found in Singapore, Brunei Darussalam, Thailand, and the Philippines. There are two countries, Malaysia and Brunei Darussalam, in which Malay people become the majority population. In these countries Malay culture serve as a national culture. The variants of Malay Language are used as national language in Indonesia, Malaysia, and Brunei Darrussalam. Base on what has been mentioned, One can said that Malay as a cultural identity is widely shared among many societies in Southeast Asia.

The Malay people traditionaly settled on the coast and in riverine enclaves. They derived their livelihood from the resources afforded by this kind of environment. They became fishermen, peasants, and traders. The role that played by Malay people in regional economic activities was that of carriers of local product traded in exchange for commodities brought to the region by merchant ships. Trading activities brought prosperity and in the seventh century it became the source of economic power for the Malay Kingdom of Sriwijaya to gain prominence position among other potentates in Southeast Asia.

According to the traditional sources, the origin of the Malay polity can be traced back to the founding of the kingdom of Sriwijaya. In thirtheen century they heyday of Sriwijaya 
ended when the Kingdom of Majapahit took her place as a dominant maritime power in western Indonesia. However, the influence of Malay was not over yet and it grow again in the fourteenth century, when a prince from Palembang, Parameswara, founded Melaka. In the fifteenth century the ruler of the kingdom of Melaka adopted Islam. It did not take a long time for Melaka to grow as an important Southeast Asia entreport and became part of Asian trading network that dominated by moslem traders. This paper will discuss the spread of Malay influences in Southeast Asia after the founding of Melaka. The discussion will be foccused on activities that was most instrumental in spreading the Malay influences, namely maritime trade.

\section{The Maritime Characteristic of Malay World}

Malay world, which geographically covers the western part of the region of Southeast Asia, occupies a strategic position. This "world" is located in a trading network that connects the Indian Ocean and South China Sea. Considering the region is spread between the Java Sea, South China Sea and the Indian Ocean, the Malay world has a very strong maritime characteristic where the sea became the main means of cultural exchange and economic activities. Since the beginning of the century various settlements in the form of port cities have sprung up in the Malay world in strategic location such as in sheltered bays or in estuaries. Although not all of these settlements and port cities growth into maritime trade centre, but some of them appear as an important regional port town which became the centre of gathering and distribution of goods called entrepôt.

Port cities that have a strategic location and have the political strength to control the trading activities in the surrounding region flourish into centres of regional and international maritime trade. Those port cities were also play a role as the driving force for the economic activities in areas under their influence. Some examples of these cities were Melaka, Aceh, Palembang, Bantam, Cirebon, Semarang and Makassar. They were first appeared as local ports which later flourishing into the centre of maritime trade activities in regional and international term. Most of them were located in the maritime trade route that has been growing before the arrival of the European. Throughout the period they transformed itself into a political power that had an ability to determine the development of trading networks in the surrounding sea region and in the inland.

\section{Global Trade}

There are two main maritime routes that became the central traffic of shipping activities in Southeast Asia, the first one is the Straits of Malacca and the second is the Sunda Strait. Political forces that have an ability to control the trading activities in the two straits will be developed into a center of political power that dominates the international maritime trade activities. An example was the Sultanate of Melaka, which was located on the Strait of Malacca, grown into an international trading city or emporium in the early of 16th century before it was captured by the Portuguese in 1511. Meanwhile, another example was the Sultanate of Banten, located near the Sunda Strait, which reached its heyday in the first half of the 17th century prior to its role as an emporium taken over by Batavia.

The Malacca Strait is a nodal point of trading network that connected the Malay world with maritime routes that stretches westward to India, Persia, the Arabian Peninsula, East Africa and the Mediterranean Sea, to the north to Siam and Pegu, and to the east to China and Japan. This trading network was one of the largest trading networks in the world at the 16th Century. The Melaka's key to success as an emporium was not because this port city was the best one, but merely because of the policies of its rulers who succeeded in forming an 
international community of merchants by imposing trade policy that can povide benefits for everyone. In addition to the policies that are conducive to the creation of the international trade community, the ruler of Melaka also provide facilities that can support the succesful of trade activities, such as ports, markets and warehouses.

In contrast to Melaka, which reached its glory without being a commodity-producing area, one of the main keys to the success of Banten to become emporium in the Sunda Strait was because of this port city controlling pepper producing areas in the western tip of Java and Lampung. Banten gained its heyday during the reign of Sultan Ageng Tirtayasa (1651-1682). During his reigned Banten had a strong maritime fleet which was built following to the European model. ${ }^{1}$ Banten fleets sailing equipped with official letters from the sultan. Throughout the seventeenth century Banten's maritime fleeets were actively involved in the maritime trading activities in the archipelago. With supports from English, Denmark and China, Banten's merchant fleets conducting trade with Persia, India, Siam, Vietnam, China, Philippines, and Japan. The Sultanate of Banten was the last major maritime power than had an ability to conduct long distance trade among other kindoms in Java.

In the history of maritime networks in Southeast Asia, port cities and straits that located in strategic place plays a decisive role. The same development can also be found in other maritime regions in various parts of the world. The aspect that made the Malay maritime world different with other regions was because the area was an entrance from the west to the spice trade activities in the 16th and 17th century. The spices from Maluccas and Banda Islands and also from Banten and western coast of Sumatra were major commodities that drives the global trading activities.

Various Nations of Asia and Europe sailed to Southeast Asia in order to find the central areas for spices production. Spieces that origanted in Souteast Asia produced in the Moluccas and Banda Islands, and pepper produced on the West Coast of Sumatra and Banten. ${ }^{2}$ The most strategic maritime roads to reach the Moluccas, Banda, and Banten was through the Malay maritime region. Therefore, since the 16th century the trading networks in Malay world fully developed and being part of global trading networks that connected Asia and other continents, especially Europe.

\section{Interaction with The Europeans}

Maritime activities in the Malay world covered a very wide geographical area. It involved people of various ethnicities, cultures, religions, and languages which were united by one activity: trading. There were many port cities that emerged along the coasts of the Indian Ocean since the 16th century until 19th century. It also occured along the coast of the Archipelago. The similar characteristics in port cities were their diverse population which consisted of a variety of people who come from different parts of Asia such as the region of Indian Ocean, the archipelago, China and various nations of Europe. Those society with a diverse backgrounds lived in groups led by someone from their own group. They lived according to their own customs and laws, but also under the authority of the ruler of those port cities which usually was a Sultan, Pangeran, or Governor General and the Dutch Hindia Council (Raad van India) in case of Batavia. ${ }^{3}$

${ }^{1}$ The development of Banten in Seventeenth century is disccuss in George Bryan Souza, The Survival of Empire: Portuguese Trade and Society in China and the South China Sea, 1630-1754 (Cambridge: Cambridge University Press, 1986), 120-123.

${ }^{2}$ Discussion about the Moluccas as a producing areas for cloves can be find in Els M. Jacobs, Merchant in Asia: The Trade of the Dutch East India Company during the Eighteenth Century (Leiden: CNWS Publication, 2006), 36-40. The cultivation of nutmeg in Banda is disscuss in Willard A. Hanna, Indonesia Banda: Colonialism and Its Aftermath in the Nutmeg Island (Philadelphia: Institute for the Study of Human Issues (ISHI), 1978). 
Many of port cities in the Indian Ocean, Southeast Asia and South China Sea since the second half of the 17th century were under the authority of the Europeans. The Portuguese was the first Europeans to landed in port cities in Asia. Their arrival was soon followed by other European nations such as Spain, Dutch, English and France. Authorities in the port cities such as Surat, Colombo and Malacca switched from one to other Europeans during the 17th and 18 th centuries.

In order to gain maximum profit from the trading activities in Asia, the Europeans build trading posts such as in Madras, Calcutta, Penang and Batavia. They were very active to seize and build new port cities in the archipelago. Their main interest was to secure the supply of spices and other commodities that could be traded in intra-Asia and international trading activities. Malacca was the first port city in the Malay that fell into the hands of the Europeans (taken over by the Portuguese in 1511). Other port cities that fell to the Europeans were: Batavia, Banten, Riau, Bengkulu, Makassar, Ambon and Timor. ${ }^{4}$ The downfall process of those port cities occured in different ways. Some captured through wars, and some fell to the Europeans through contracts.

Although many of the important port cities in the archipelago fell into the hands of Europeans, but it did not mean the Malay maritime trading activities in the 17th and 18th centuries had receded. It was because the Europeans were not able to control the entire sector of maritime trade and their interest was only to commodities that could be sold in international market. A study on the trading activities in the North Coast of Java in 1755 showed that the indigenous traders remain active to trade various commodities such as rice, fish, vegetables and textiles from one port city to another port city in a significant quantity. ${ }^{5}$ It proves that the European domination of the Malay maritime world only occured in commodities that were salable in global market.

\section{Trade around the Straits of Melaka}

In the early 17th century, A Sultanate of Aceh that located at the northern tip of Sumatra emerged as an important Islamic port city by taken over the role of Malacca. This Sultanate reached its heyday and became rullers of the West Coeast of Sumatra when it was under the rule of Sultan Iskanda Muda (1607-1636). ${ }^{6}$ Aceh's territory stretches from the Deli in the East Coast of Sumatra to the Padang on the west coast. For several years Aceh had also territories in several parts of the Malay Peninsula. As well as Banten, Aceh was one of the major producers of pepper in the archipelago. The sultanate's capital city, Banda Aceh, became an important trading center in Asia.

Another important port cities around and beyond the Malacca Strait which plays a strategic role in the trade network in the Southeast Asia were Johor-Riau, Siak, Batavia, Makassar and various port city on the North Coast of Java such as Cirebon, Semarang, Tuban, and Surabaya. These port cities werre connected with the wider trading networks that

${ }^{3}$ The power arrangement in the city of Batavia is discussed in Bondan Kanumoyoso, "Beyond the City Wall Society and Economic Development in the Ommelanden of Batavia," (Leiden: Unpublished PhD Thesis, 2011), 4779.

${ }^{4}$ Early European colonial penetration into Indonesia is discussed in M.A.P. Meilink-Roelofsz, Asian Trade and European Influence in the Indonesian Archipelago Between 1500 and About 1630 (The Hague: Martinus Nijhoff, 1962).

\footnotetext{
${ }^{6}$ About Aceh under the rile of Sultan Iskandar Muda see Denys Lombar, Le Sultanat d'Atjeh au temps d'Iskandar Muda, 1607-1636 (Paris: Ecole Francaise d'Extreme-Orient, 1967).
}

${ }^{5}$ See Gerrit Knaap, Shalow Waters, Rising Tide. Shipping and trade in Java around 1775 (Leiden, KITLV, 1996). 
stretched from China to the Indian subcontinent. At the same time these port cities also served as a port for the collection and distribution of small port towns in the regional level.

The Sultanate of Riau, which was located on the south of the Strait of Malacca, began to grow into a major port city in the middle of 17th century. After the death of the last sultan in 1699, the kingdom was in the situation of power struggle between the followers of royal officials, especially betwen the treasurer and admiral. ${ }^{7}$ The contest for power became more complicated after the Bugis nobles of South Sulawesi, who fled to the region in order to avoids the Dutch power in their place of origin, began to get involved. In the early 18th century the political power in the Sultanate of Riau-Johor gradually fall into the hands of the Bugis nobles. When Riau directly under the rule of Bugis nobles, who very famous for their skill as traders, this kingdom grew into one of the centre of trading activities in the Straits of Malacca. During that period merchant from various places in the archipelago, China, India, and Europe came to Riau to conduct trade.

In the late 18th century, Riau engaged in a conflict with the Dutch that settled in Melaka. A little conflict between a Bugis leader, Raja Haji, and the Dutch governor in Melaka led to open warfare in 1784 that ended with the defeat of Riau. The defetad of Riau by the Dutch became the reason for the Bugis traders to find other places that could provide safety for them in doing trade. Therefore they went to other port cities in the Strait of Malacca and the Malay Peninsula on the East Coast. This is the explanantion why the war that won by the Dutch did not lead to the destruction of trade activities of Bugis traders. They were able to continue their trading activities on the port cities such as Selangor, Johor, Terengganu and Siak.

Another important port city around the Strait of Malacca was Siak. This port town was located on the East coast of Sumatra. Siak could grow into an important port city because it was functions as a link connection between the Straits of Malacca and the interior of Sumatra whose population was quite dense and could only be reached by transport through river. Prior to the nineteenth century, the Inland areas of Sumatra island was the main producing areas for forest products such as rattan, wood and resin. Another product form this region were gold and pepper. Siak became the place for the marketing of product from inland areas and connected the areas with the port city of Melaka, whic was the most importan port city in the regional level.

\section{The Dynamics of Java Sea}

During the 17th and 18th centuries some important port cities around the Java Sea were Bantam, Batavia, Cirebon, Semarang and Makassar. In these port cities there were communities of Malay merchants who are actively involved in maritime trade activities. The existence of this comunity made the port cities on the North Coast of Java and South Sulawesi to be part of the vast Malay trading network.

Throughout the 17th and 18th centuries Batavia was the hub for the VOC activities (Verenigde Oost-Indische Compagnie / Airlines Trade East Indies) in Asia and became one of the most important emporium in the global trading network. Batavia was not only play a role as as rende-vous for the Dutch ships in the intra-Asian trade but also it also serve as the centre for the Dutch long distance trade between Asia and Europe. This port city had complete trading facilities and even it had a facility of shipyard for the ships repairement that located on the Onrust Island in the Bay of Jakarta. The ships that being repaired in Onrust were not only VOC ships but also private merchant ships and other ships from various European countries.

${ }^{7}$ Leonard Andaya, The History of Johore 1641-1728: Economic and Political Development (Kuala Lumpur: Oxford University Press, 1975). 
Batavia had a very strategic geographical location, it was situated near the Sunda Strait which is, together with the Straits of Malacca, function as a sea connection line between the Indian Ocean and South China Sea. Considering this strategic posistion batavia was very appropriate to become the centre for VOC activities in Asia. Other than being a rendez-vous place for the VOC ships, Batavia subsequently also growth into one of the major port city in the Asian trading network. This port city also became the centre of the Dutch military activity in the competition to protect and expand trading activity with the Portuguese and Spanish in Asia.

Trade system that developed in Batavia was basically a dsitribution trading system. In this system, commodities from across Asia gathered in this port city before it was distribute to areas that have a potential market and could provided big profits. In general, in the VOC's perspectice, there were three categories of regions where they have economic interests. ${ }^{8}$ First; the colonies where they have territorial possesion such as in Sri Lanka, Malacca, Batavia, and Maluku. Second; the region where they had a special contract with the local potentates to be allowed to open a trade office or factorij like in Ayuthaya (Siam). Third; regions where they had to trade with the supervision and regulation applied by local authorities such as in Nagasaki (Japan), and Canton (China mainland).

In 1724 Francois Valentijn published his work containing records of intra-Asian trade activities carried out by the VOC through the port city of Batavia. ${ }^{9}$ In his work Valentijn said that countries and regions which were involve in trade with Batavia include: Cape of Good Hope (South Africa), Coromandel, Ceylon, Persia, Bengal, Burma, Malacca, Siam, Tonkin, China, and Japan. The Goods imported by Batavia form these areas include: gold coins and copper (Japan), textiles (Coromandel and Bengal), tea (China), porcelain (China), silk (China), ivory (Siam ), ebony (Cape of Good Hope), and slaves (Coromandel, Bengal and Burma). While the commodities exported by Batavia to those reions were: spices (Europe) textiles (Japan, Siam, and the Cape of Good Hope), sugar (Persian, Bengal, and Japan), and rice (Cape of Good Hope), and slaves (Cape of Good Hope and Malacca).

Contrary to Batavia that was under the European rulers, Makassar was a port city that was under the control of local authority. This port city emerged into an important centre of maritime trade in the early 17th. The rulers Makassar supported the maritime trade activities by applying a low tax policy and directly involved in the dispatch of merchant ships to Malacca and other port cities in the west of the archipelago. According to the European sources, one of the sultan policies that supported the trade activities were free-tax for goods imported from outside (import). ${ }^{10}$

Sultan also did not restrict the export of gold, silver and spices. The main goal of the Makassar was not the expansion of maritime trade activity but the profit from these activities allowed the sultan and his people to strengthen their military force and navy. The glorious period of Makassar ended in 1666 with the signing of the Bongaya agreement between the VOC and Sultan Hasanuddin. Since that time Makassar fell to the Dutch and the rest of Makassar trading network that stretched from Malacca to Eastern Indonesia taken over by the Dutch.

\section{Conclusion}

${ }^{8}$ Leonard Blussé, Visible Cities: Canton, Nagasaki and Batavia and the Coming of the Americans (Cambridge: Harvard University Press, 2008), 34-35.

${ }^{9}$ Fracois Valentijn as cited by Leonard Blussé, “On the Waterfront: Life and Labour Around the Batavian Roadstead" in Haneda Masashi (editor), Asian Port Cities 1600-1800. Local and Foreign Cultural Interactions (Singapore: NUS Press, 2009), 132-134.

${ }^{10}$ Souza, The Survival of Empire, 88. 
Malay maritime network was one of the world's most important maritime network. Malay world occupied a strategic position within the global trading network because of its geographic areas was the center of maritime crossing that connected the Indian Ocean with the Java Sea and the South China Sea. Malay maritime world was also the main entrance to the spices producing areas in the western and eastern part of Indonesia.

For centuries, trading activities had brought many influences to the people living in the maritime Southeast Asia. These included the influence of religion, political systems, economic, ethnic composition, language, way of life and so on. Maritime trading activities did not only exchange goods, but also the values and culture. Many things changed, but there were also things that were united through maritime trade activities. One prominent thing from the trading activities in the Malay world was the emergence of Malay language as a bridge or a "lingua franca" for the ethnics and nations who lived in Southeast Asia. The Malay maritime world trading activities had created a bond among the various nations in Southeast Asia through the use of a common language which later became the national language of Indonesia, Malaysia and Brunei Darussalam.

\section{References}

Andaya, Leonard. The History of Johore 1641-1728: Economic and Political Development. Kuala Lumpur: Oxford University Press, 1975.

Blussé, Leonard. "On the Waterfront: Life and Labour Around the Batavian Roadstead" in Asian Port Cities 1600-1800. Local and Foreign Cultural Interaction, ed. Haneda Masashi (Singapore: NUS Press, 2009), 132-34.

Blussé, Leonard. Visible Cities: Canton, Nagasaki and Batavia and the Coming of the Americans. Cambridge: Harvard University Press, 2008.

Hanna, Willard A. Indonesia Banda: Colonialism and Its Aftermath in the Nutmeg Island. Philadelphia: Institute for the Study of Human Issues (ISHI), 1978.

Jacobs, Els M. Merchant in Asia: The Trade of the Dutch East India Company during the Eighteenth Century. Leiden: CNWS Publication, 2006.

Kanumoyoso, Bondan. Beyond the City Wall Society and Economic Development in the Ommelanden of Batavia. Leiden: Unpublished PhD Thesis, 2011.

Knaap, Gerrit. Shalow Waters, Rising Tide. Shipping and trade in Java around 1775. Leiden, KITLV, 1996.

Lombar, Denys. Le Sultanat d'Atjeh au temps d'Iskandar Muda, 1607-1636. Paris: Ecole Francaise d'Extreme-Orient, 1967.

Meilink-Roelofsz, M.A.P. Asian Trade and European Influence in the Indonesian Archipelago Between 1500 and About 1630. The Hague: Martinus Nijhoff, 1962.

Souza, George Bryan Souza. The Survival of Empire: Portuguese Trade and Society in China and the South China Sea, 1630-1754. Cambridge: Cambridge University Press, 1986. 